\title{
The Effectivity of Virtual Tour as an Alternative of Ecotourism Method: A Case Study of Tambora National Geopark, Indonesia
}

\author{
Diah Rahmawati ${ }^{1, *}$ Alpiana $^{1}$ Joni Safaat Adiansyah ${ }^{1}$
}

\author{
${ }^{1}$ Mining Engineering, Universitas Muhammadiyah Mataram, 83127, Indonesia \\ *Corresponding author. Email: dee.rahmawati@gmail.com
}

\begin{abstract}
The Covid-19 pandemic has an impact on the tourism sector. Virtual tours become an alternative to adapt to the Covid19 pandemic. The Geotourism Festival held online in June 2020. However, the environmental conditions such as endemic flora, fauna, landscapes, and ecosystem services could not be covered by the virtual tour. This paper is aimed to find out the prospect of a virtual tour as an alternative method for ecotourism in Tambora Geopark. The method used in this paper was interviews with two primary respondents, namely Tambora's Geopark Managers and virtual tour participants at the Geotourism Festival Event. The results were analyzed using SWOT analysis to obtain a virtual tour effectivity. The result showed some possible strategies to improve virtual tourism in Tambora Geopark such as making an android-based application about geosites and the Tambora Geopark's facilities, improving the English skills of the local interpreter, improve the quality of 3D videos and photos with a detailed narrative, and the Tambora Geopark Manager must cooperate with various parties. The concept of Virtual Tourism as an alternative method for ecotourism that can be applied in Tambora Geopark is combining ecotourism and geotourism by adding information about the ecological conditions in each geosite.
\end{abstract}

Keywords: Mud Eco-Tourism, Tambora National Geopark, Virtual Tour.

\section{INTRODUCTION}

For numerous developed and developing countries, the tourism division may be a significant business source, government income, and foreign trade earnings. Epidemics and pandemics are two of the most frightening news for travelers. The tourism industry has experienced firmly falling incomes and is a financial segment among those most seriously influenced by the pandemic [1].

During the second quarter of 2020, World Tourism Organization (WTO) announced that $100 \%$ of worldwide tourism trips were rescheduled or even cancelled. In addition, the global travel industry has been completely suspended, and diminished by lockdown conditions forced in numerous countries. It caused travel limitations from different places with affirmed cases to reduce the pandemic's spread. Some of tourism destination have begun gradually to open, however some travel agent could not operate normally due to the transportation [2]. The COVID-19 pandemic caused a health and economic crisis [3].
Based on Covid-19 data on November $12^{\text {th }}, 2020$ [4], the number of infected covid-19 in West Nusa Tenggara Province was 4.355 , with details of being treated as 508 people, recovered 3.615 people and died 232 people. In terms of zoning, Dompu and Bima Regencies are included in the moderate risk zone (orange zone) while other regencies and cities are yellow zones.

Until now, the level of tourist visits in NTB is still low and is still dominated by domestic tourists. One of the efforts developed to adapt to the Covid-19 pandemic in the tourism sector is a virtual tour. One of the events that have carried out a virtual tour in West Nusa Tenggara Province is the geotourism festival held online in June 2020 by presenting various videos about the geosite in the Tambora Geopark area voiceover by a local tour guide/interpreter. However, the virtual tour presented has not yet touched on environmental conditions in the Tambora geopark area, such as endemic flora and fauna, landscapes, and ecosystem services that support tourism activities in the region. The Tambora geopark area's width and the limitation of visitor's holidays make the virtual tour an alternative method to introduce 
ecotourism/ecological conditions in the Tambora Geopark area.

This paper is aimed to find out the prospect of a virtual tour as an alternative method for ecotourism in Tambora Geopark. A case study of Tambora National Geopark was taken due to the impact of covid-19 in tourism.

\section{METHOD}

The methods used in this paper are qualitative research with literature review and interviews. The respondents are the Tambora National Geopark Managers and virtual tour participants at the Geotourism Festival Event. The interview results were analyzed using
SWOT analysis to obtain an alternative strategy applied to ecotourism in the Tambora Geopark area.

\section{RESULT AND DISCUSSION}

\subsection{Tambora National Geopark [5]}

Tambora Geopark is one of the National Geopark established in 2017. Tambora Geopark is located on Sumbawa Island, Bima Regency, and Dompu Regency, NTB Province. The Tambora Geopark area consists of 4 districts, namely Kempo district, Pekat District, Sanggar District, and Tambora District. Tambora Geopark has an area of $2,130 \mathrm{~km}^{2}$ with 33 villages. Figure 1 shown Tambora Geopark's Location.

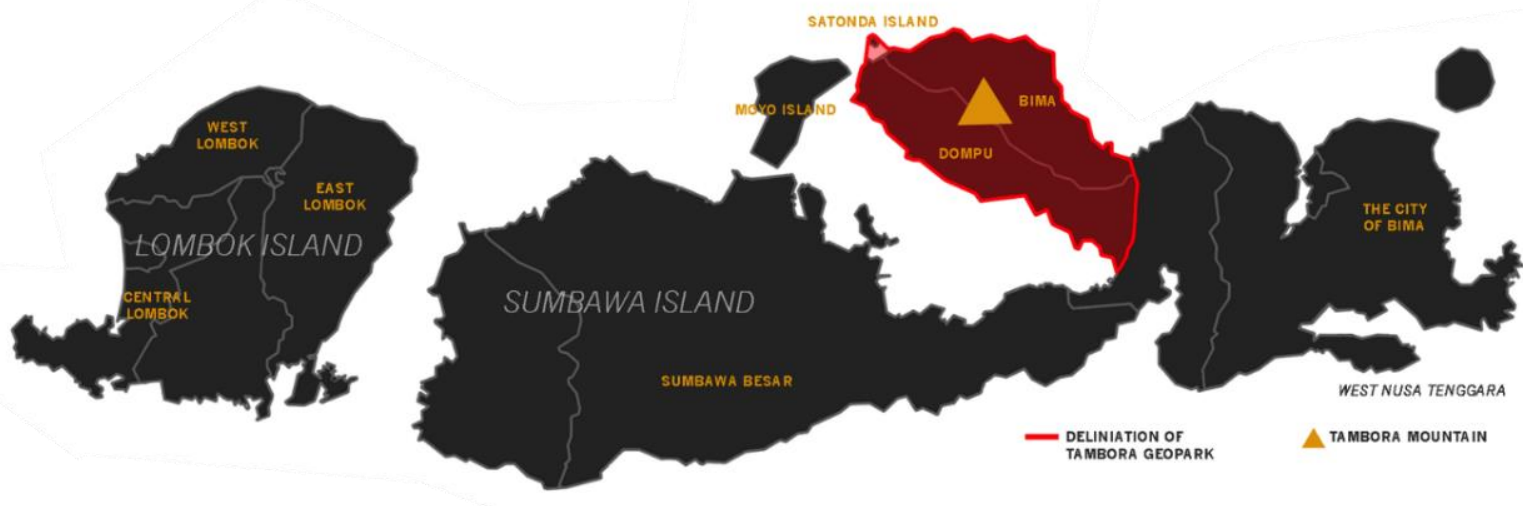

Figure 1 Tambora Geopark’s Location

Geological processes for thousands to millions of years have resulted in various potential geodiversity ini Mount Tambora and its surrounding areas, ranging from caldera, volcanoes, cylindrical cones, waterfalls, to beaches and volcanic islands. Tambora Geopark also has a diversity of flora, fauna, and landscape. Some flora and fauna are endangered, such as kakatua jambul kuning (Cacatua sulphurea), even Rusa Timor (Cervus timorensis), and Benuang Laki (Duabanga moluccana). Both of them are the mascot of West Nusa Tenggara Province. There are 275 species of flora in the Tambora Forest area. According to the sea level, the Tambora Forest area is divided into three ecosystems: monsoon forest, tropical rainforest, and savanna forest. According to the concept of Geopark, geological heritage sites are part of the holistic concept of protection, educations and sustainable development. Synergies between geological, biological and cultural diversity should be highlightes as an integral part of a geopark especially if the landscape and geological value can be shown to visitors.

\subsection{SWOT Analysis}

Based on all respondents' responses, the following are strengths, weaknesses, opportunities, and threads associated with the virtual tour in Tambora Geopark as presented in Table 1.
Based on the SWOT analysis, there are some possible strategies to improve virtual tourism in Tambora Geopark.

a. S-O strategies: Increase the online product sales, making an android -based application that contains geosite locations, transportation facilities, geohomestay, geoproduct, geotracking services, and tour packages, conducting Tambora Geopark interpreter's training, certify tourism guides, highlighting biodiversity by developing ecotourism in geopark area.

b. S-T strategies: Provide complete and exciting information, promote the uniqueness of the Tambora Geopark

c. W-O strategies: Improving the English skills of the local interpreter, the cost of making videos can be taken from the budget of the relevant agencies, maximize cooperation with village governments in geopark management

d. W-T strategies: improve the quality of 3D videos and photos, the videos equipped with a detailed narrative 
Tabel 1. The SWOT Analysis of Virtual Tour in Tambora Geopark

\begin{tabular}{|c|c|c|c|}
\hline Strengths & Weaknesses & Opportunities & Threads \\
\hline $\begin{array}{l}\text { The virtual tour can be } \\
\text { accessed by the wider } \\
\text { community/ internationally/ } \\
\text { everywhere }\end{array}$ & High cost & $\begin{array}{l}\text { Community empowerment } \\
\text { through training }\end{array}$ & $\begin{array}{l}\text { The level of tourist satisfaction } \\
\text { is lower than making a direct } \\
\text { visit to the sites }\end{array}$ \\
\hline $\begin{array}{l}\text { provide information about the } \\
\text { entire geopark area }\end{array}$ & $\begin{array}{l}\text { there are still blind spot } \\
\text { locations in the Tambora } \\
\text { Geopark area that cannot be } \\
\text { accessed by the internet }\end{array}$ & $\begin{array}{l}\text { Revive the economy of the } \\
\text { community around the } \\
\text { Tambora Geopark }\end{array}$ & $\begin{array}{l}\text { The Quality } \\
\text { Video/Documentary film still } \\
\text { inadequate }\end{array}$ \\
\hline $\begin{array}{l}\text { visitors can do good planning } \\
\text { about their trip/vacation }\end{array}$ & $\begin{array}{l}\text { the English skill of local } \\
\text { interpreter must be improved }\end{array}$ & $\begin{array}{l}\text { Can cooperate with various } \\
\text { agencies }\end{array}$ & $\begin{array}{l}\text { The Existence of Rinjani } \\
\text { Unesco Global Geopark }\end{array}$ \\
\hline $\begin{array}{l}\text { Support from the local } \\
\text { community }\end{array}$ & & $\begin{array}{l}\text { An alternative method during } \\
\text { covid }-19 \text { pandemic }\end{array}$ & \\
\hline $\begin{array}{l}\text { Tambora Geopark has high } \\
\text { biodiversity, some of which } \\
\text { are endangered species that } \\
\text { must be protected }\end{array}$ & & & \\
\hline
\end{tabular}

\subsection{Discussion}

Virtual tourism development in Tambora Geopark is a high-cost event because it requires a lot of video/documentary films to present the entire geopark area, not only the geosites and their geological history but also environmental conditions around the geosites. In addition, there are still blind spot locations that cannot be accessed by the internet. The same thing was stated by Voronkova [4], that developing virtual tourism is impeded by the equipment, which is expensive, and a small number of digitalized tourist destinations. The intuitive substance must turn into a need for virtual gadget creators and the business, culture, education, and production sectors. Visualization makes a difference to advance destinations' positive image, leading to their financial improvement due to the growing number of tourists. The utilization of web innovation, such as online travel communities, offers visitors an opportunity to seek travel information, make connections with others, and make travel choices more helpfully and cost-effectively [6].

With Virtual Tourism, visitors can determine the location visited from their home. Vacation always seems too short because visitors never see everything they desire during their trip, mostly because of poor planning. By Virtual tour, they can get a 3D tour of that location before arriving at the destination and feel the local community's culture before arriving. It can help the traveler to find places on the map faster and help the traveler locate simple things like the nearby coffee shop, restaurant \& shops

The visitor not only gets information about the geological history of each geosite but also the story about the ecosystem around the geosite.
Visitors are not only presented by the view, but also get information about the Tambora Geopark. Developing ecotourism must also prioritize the involvement of the community in the form of exchange of ideas, decisionmaking, actions, and control in developing rural tourism activities. Both human resources and natural resources can be maximally achieved [7]-[11] as shown in the Geopark Tagline: Glorify the Earth's Heritage, Prosper the Community. The local community involvement in virtual tourism management will revive their economy, especially in the Covid-19 pandemic

A virtual tour is very effective in a covid-19 pandemic situation. People can get information about Tambora Geopark from their homes. In post-pandemic, a virtual tour can be the source of information about the destination before visiting the area so that the visitor can make a good plan about their trip. A virtual tour can also be the source of information for academics, researchers, etc. not only in geology but also in the environmental and socio-cultural field.

\section{CONCLUSION}

Tambora Geopark must cooperate with various parties to make it happen. making direct visits. However, it needs a large investment to develop a virtual tour. The managers of the The virtual tour is an alternative tourism method that can be developed because of its extensive accessibility and can be enjoyed by all people, even for people with disabilities and older people who have difficulties

\section{ACKNOWLEDGMENTS}

We would like to thanks to Tambora Geopark's Managers for providing data on the Tambora National Geopark. 


\section{REFERENCES}

[1] N. G. Uğur and A. Akbıyık, "Impacts of COVID-19 on global tourism industry: A cross-regional comparison," Tour. Manag. Perspect., vol. 36, no. April, p. 100744, 2020, doi: 10.1016/j.tmp.2020.100744.

[2] B. Gopalakrishnan, R. Peters, and D. Vanzetti, "Covid-19 and Tourism," Econ. Consequences, no. July, pp. 1-27, 2020.

[3] T. Haryanto, "Editorial: Covid-19 Pandemic and International Tourism Demand," J. Dev. Econ., vol. 5, no. 1, p. 1, 2020, doi: 10.20473/jde.v5i1.19767.

[4] GOI, "Covid-19 Data in West Nusa Tenggara Province," 2020. [Online]. Available: https://corona.ntbprov.go.id/. [Accessed: 12-Nov2020].

[5] Dewan Pelaksana Geopark Tambora, Geopark Tambora; Aspiring Unesco Global Geopark. Mataram, NTB, Indonesia: BAPPEDA Provinsi NTB, 2019.

[6] S. Rahman and D. A. Bhowal, "Virtual Tourism and Its Prospects for Assam," IOSR J. Humanit. Soc.
Sci., vol. 22, no. 2, pp. 91-97, 2017, doi: 10.9790/0837-2202019197.

[7] A. Siswanto and M. Moeljadi, "Eco-Tourism Development Strategy Baluran National Park in the Regency of Situbondo, East Java, Indonesia," Int. J. Eval. Res. Educ., vol. 4, no. 4, p. 185, 2015, doi: 10.11591/ijere.v4i4.4510.

[8] J. Belsoy, J. Korir, and J. Yego, "Environmental Impacts of Tourism in Protected Areas," J. Environ. Earth Sci., vol. 2, no. 10, pp. 64-73, 2012.

[9] S. Meei Lee and H. Chris Honda, "The Implementation of Green Tourism and Hospitality," J. Tour. Hosp., vol. 5, no. 4, 2016, doi: 10.4172/2167-0269.1000233.

[10] D. Cahyaningrum, “Community Empowerment Based Local Wisdom In Tourism Of Bajo Community, Wakatobi," Int. J. Sci. Technol. Res., vol. 6, no. 11, pp. 196-201, 2017.

[11] S. Khalid, M. S. Ahmad, T. Ramayah, J. Hwang, and I. Kim, "Community empowerment and sustainable tourism development: The mediating role of community support for tourism," Sustain., vol. 11, no. 22, 2019, doi: 10.3390/su11226248. 